\title{
INTERAKSI PEMBELAJARAN MENULIS PARAGRAF DEDUKTIF PADA MAHASISWA FKIP UNIVERSITAS TRIDINANTI PALEMBANG
}

\section{(Learning Interaction of Deductive Pharagraph Writing on the Student of FKIP Tridinanti University Palembang)}

\author{
Doni Samaya \\ Universitas Tridinanti Palembang \\ Jl. Kapten Marzuki No. 2446 Kamboja, Palembang, Telp. 0711355961 \\ donisamaya25@gmail.com
}

Diterima 9 Mei 2019

Direvisi 25 Juni 2019

Disetujui 26 Juni 2019

\begin{abstract}
Abstrak: Penelitian ini berawal dari pengamatan peneliti bahwa kebanyakan mahasiswa masih belum mampu menulis paragraf dengan benar. Selama ini mahasiswa hanya asal menulis tanpa memperhatikan konsep paragraf yang benar sehingga menyebabkan banyaknya kesalahan dalam penulisan paragraf khususnya paragraf deduktif. Penelitian ini bertujuan untuk mendeskripsikan interaksi antarmahasiswa, mahasiswa dengan dosen, dan dosen dengan mahasiswa. Selain itu, penelitian ini juga bertujuan untuk mengetahui faktor-faktor yang memengaruhi mahasiswa dalam menulis paragraf deduktif. Metode penelitian ini menggunakan metode kombinasi antara kualitatif dan kuantitatif. Pengumpulan data dalam penelitian ini dilakukan dengan angket semi tertutup, tes unjuk kerja menulis paragraf deduktif, dan observasi berperan serta. Data hasil angket semi tertutup dipersentasekan dengan jelas; data hasil tes menulis dideskripsikan berdasarkan rubrik penilaian menulis paragraf deduktif oleh Oshima dan Hogue; dan data hasil observasi berperan serta juga dideskripsikan dengan jelas. Berdasarkan analisis data peneliti memeroleh hasil bahwa 1) terdapat beberapa faktor yang memengaruhi mahasiswa dalam menulis paragraf deduktif; 2) terdapat tiga interaksi pembelajaran dalam menulis paragraf deduktif pada mahasiswa FKIP Universitas Tridinanti Palembang.
\end{abstract}

Kata kunci: interaksi pembelajaran, menulis, paragraf deduktif.

\begin{abstract}
This research starts from the researchers' observation that most students still haven't been able to write paragraphs correctly. During this time, students just write without regard to the concept of the right of the paragraph so that it causes a large number of errors in the writing of a paragraph especially deductive paragraph. This study aims to describe the interaction of the students with lecturers, students and lecturers. In addition, the study also aims to find out the factors that affect of the students in writing a deductive paragraph. Method of this research was using a combination of qualitative and quantitative. The collection of data in this study was conducted with the questionaire of enclosed, test the deductive paragraph writing performance, and useful observations. The questionqire closed spring results data would be presentation clearly; results of writing test data is described based on deductive paragraph writing assessment rubric by Oshima and Hogue (2006); data and observations are also useful is described clearly. Based on analysis of data researchers get results that 1) there were some factors which influence the students in writing deductive paragraph; 2) there were three learning interactions in writing deductive paragraph of students in FKIP Tridinanti University of Palembang.
\end{abstract}

Keywords: interaction of learning, writing, deductive paragraph. 


\section{PENDAHULUAN}

Menulis merupakan keterampilan berbahasa yang tertinggi setelah menyimak, berbicara, dan membaca. Oleh sebab itu, menulis dapat dikatakan keterampilan berbahasa yang sangat kompleks. Keterampilan ini tidak begitu saja muncul tanpa dilatih terlebih dahulu. Agar terampil dalam menulis, seseorang harus banyak melakukan latihan. Selain itu, banyak tidaknya kegiatan membaca juga memengaruhi kemampuan menulis seseorang. Hal ini tidak dipungkiri lagi bahwa bagus tidaknya tulisan seseorang tergantung seberapa banyak bahan bacaan yang telah dibaca sehingga seseorang akan banyak memperoleh kosakata untuk dapat dituangkan dalam tulisan.

Aktivitas menulis sangatlah penting, terutama bagi mahasiswa calon guru Bahasa Indonesia. Kegiatan ini tidak dapat dipisahkan dari kegiatan belajar mengajar. Hampir pasti bahwa semua kegiatan pembelajaran di kelas diikuti dengan kegiatan menulis. Contohnya mahasiswa menulis dalam rangka penyelesaian tugas yang diberikan dosen. Akan tetapi, mahasiswa tidak menyadari bahwa tulisan yang mereka buat masih salah. Hal ini disebabkan oleh ketidaktahuan mereka dengan konsep menulis yang sesungguhnya, khususnya dalam menulis ilmiah.

Bentuk kegiatan menulis pada kegiatan belajar mengajar atau pada kegiatan apa pun adalah menulis paragraf. Sebenarnya, menulis paragraf bukanlah hal yang sulit. Namun, ini hanya berlaku pada seseorang yang sudah paham dengan konsep paragraf yang sesungguhnya. Paragaf yang sesungguhnya memiliki satu topik pembahasan dan strukturnya jelas. Jadi, disimpulkan bahwa paragraf itu merupakan gabungan dari beberapa kalimat, membahas satu topik atau kesatuan ide yang jelas, dan mempunyai struktur yang jelas sesuai dengan jenis paragrafnya.
Lebih lanjut, suatu paragraf yang tepat itu sebenarnya tidak terlalu memerhatikan banyaknya kalimat dalam satu paragraf karena itu bukanlah hal yang penting. Hal yang harus diperhatikan dalam suatu paragraf adalah kalimat topiknya dapat dikembangkan secara jelas. Kejelasan topik ini didukung oleh kalimatkalimat penjelas, tetapi harus tidak keluar dari ide pokok tersebut. Berapa pun banyaknya kalimat penjelas yang digunakan itu bukanlah suatu masalah. Asalkan kalimat-kalimat tersebut masih membahas satu topik, paragraf itu adalah benar.

Materi paragraf baik di sekolah maupun di perguruan tinggi pasti diajarkan. Paragraf deduktif adalah salah satu jenisnya. Paragraf deduktif merupakan paragraf yang letak kalimat utamanya di awal paragraf. Struktur paragraf ini paling umum dibandingkan paragraf lainnya. Paragraf ini berpola umum ke khusus sehingga sangat mudah untuk membutanya.

Salah satu tujuan khususnya pada Mata Kuliah Menulis di Program Studi Pendidikan Bahasa Indonesia di Universitas Tridinanti Palembang adalah mahasiswa mampu menuliskan dan menuangkan gagasan atau ide dalam suatu paragraf dengan tepat. Berdasarkan hal tersebut, logikanya mahasiswa mampu menulis paragraf dengan tepat setelah diajarkan materi paragraf tanpa terkecuali paragraf deduktif.

Walapun demikian, antara harapan dan kenyataan masih belum sesuai. Harapan atau rencana dalam tujuan instruksional di atas masih berbanding terbalik dengan kenyataan yang ada di lapangan. Hal ini diketahui dari pengalaman peneliti dalam pembelajaran bahwa kebanyakan mahasiswa masih kesulitan dalam memahami dan menuliskan kalimat efektif. Selain itu, mahasiswa masih kesulitan mengorganisasikan ide dalam paragraf sehingga paragraf yang dibuat menjadi 
kurang tepat. Hal ini diketahui dari hasil penilaian tulisan mahasiswa dalam menulis paragraf atau tugas lainya.

Berikut ini adalah data pendukung berupa jurnal penelitian tentang paragraf deduktif. Hal ini menunjukkan bahwa betapa pentingnya menulis paragraf yang benar. Penelitian pertama dilakukan oleh Azis (2015) hasilnya adalah terdapat 34 paragraf tulisan mahasiswa yang belum koheren. Penelitian yang kedua oleh Pramesti dan Efendi (2018). Penelitian ini bertujuan untuk meningkatkan hasil belajar menulis paragraf oleh mahasiswa di UNP melalui model STAD. Penelitian yang ketiga oleh Mardiyah (2016) bahwa keterampilan menulis siswa dalam menulis dapat ditingkatkan dengan cara menerapkan pengembangan struktur paragraf.

Selain itu, dewasa ini fenomena tentang paragraf yang benar masih diabaikan tanpa terkecuali oleh para mahasiswa. Biasanya mereka hanya asal menulis dan menggabungkan beberapa kalimat tanpa memperhatikan konsep paragraf yang benar. Tampaknya sudah menjadi kebiasaan mereka bahwa paragraf hanya berupa gabungan dari kalimat sehingga dengan bebasnya menuliskan topik yang beragam dalam satu paragraf. Padahal, dalam menulis paragraf ada ketentuannya kapan topik itu dituliskan satu paragraf atau kapan topik itu dituliskan pada paragraf berikutnya.

Berdasarkan hasil pengamatan peneliti, terdapat beberapa alasan peneliti melakukan penelitian ini. Alasan yang pertama, masih banyaknya mahasiswa yang belum paham dengan konsep paragraf; Alasan yang kedua, masih banyaknya mahasiswa yang belum mampu menulis paragraf dengan benar; Alasan yang ketiga, masih banyaknya mahasiwa yang menganggap menulis paragraf itu mudah; dan alasan yang keempat masih banyaknya mahasiswa yang menganggap bahwa dalam paragraf tidaklah berbeda dengan kegiatan mengarang bebas.
Berdasarkan latar belakang di atas, permasalahan penelitian ini dapat dirumuskan secara rinci dalam beberapa bentuk pertanyaan berikut ini.

a. Apa sajakah faktor yang memengaruhi mahasiswa dalam menulis paragraf deduktif?

b. Bagaimanakah interaksi pembelajaran dalam menulis paragraf deduktif pada mahasiswa FKIP Universitas Tridinanti Palembang?

\section{KERANGKA TEORI \\ 2.1 Definisi Menulis}

Menulis merupakan suatu proses pengungkapan pikiran dan perasaan seseorang dalam bentuk tulisan. Pengungkapan ide inilah yang dinamakan suatu proses karena itu menulis bukanlah sesuatu yang mudah untuk dilakukan. Hal ini senada dengan pendapat Nurgiyantoro (2001) bahwa keterampilan menulis menuntut penulis untuk menguasai berbagai unsur di luar kebahasaan itu sendiri yang akan menjadi isi dalam suatu tulisan (hlm. 271).

Sedikit berbeda dengan Kurniawan (2012) mengatakan bahwa menulis adalah kegiatan kegiatan menentukan dan menggabungkan kalimat agar pesan, informasi, dan maksud dapat disampaikan dengan baik. Pesan yang dimaksud adalah makna yang terkandung dalam tulisan, sedangkan penggabungan kalimat digunakan penulis (ejaan dan tanda baca) agar informasi menjadi lebih jelas (hlm. 44). Lebih lanjut, DePorter (2008) mengemukakan bahwa menulis adalah aktivitas seluruh otak yang menggunakan belahan otak sebelah kanan (emosional) dan belahan otak sebelah kiri (logika). Aktivitas otak kanan untuk keterampilan menulis meliputi semangat, spontalitas, emosi, warna, imajinasi, gairah, ada unsur baru, dan kegembiraan. Kemudian aktivitas otak sebelah kiri meliputi perencanaan, outline, tata bahasa, penyuntingan, penulisan kembali, penelitian, dan tanda baca (hlm. 179). 
Dari ketiga pendapat di atas, disimpulkan bahwa menulis adalah suatu proses merangkai kata-kata dan kalimat yang berupa pesan/informasi dengan melibatkan aktivitas otak kanan dan otak kiri dengan tulisan sebagai wahananya. Dengan demikian, menulis merupakan satu keterampilan berbahasa yang sangat penting untuk dikuasai sehingga dapat menyampaikan pesan dengan tepat.

Berdasarkan definisi di atas dapat disimpulkan bahwa menulis merupakan suatu proses yang kompleks. Oleh sebab itu, keterampilan menulis harus dilakukan berdasarkan langkah-langkah tertentu. Hal ini senada dengan pendapat Clark (dikutip Zainurrahman, 2013) bahwa langkahlangkah dalam menulis itu ada tiga, yaitu: (1) perencanaan, (2) penulisan, dan (3) revisi (hlm. 11).

1. Tahap Prapenulisan

Secara umum pada tahap prapenulisan ini terdapat bebarapa aktivitas yang harus dilakukan, di antaranya: 1) menentukan topik, 2) menentukan kerangka ide, 3) menentukan maksud atau tujuan penulisan, 4) memerhatikan sasaran karangan atau mempertimbangkan pembaca, 5) mempertimbangkan konteks, (6) mengumpulkan informasi pendukung, dan (7) mengorganisasikan ide serta informasi.

2. Tahap Penulisan

Pada tahap ini, hal-hal yang harus diperhatikan adalah (1) fokus pada ide yang telah dibuat sebelumnya; (2) konsistensi dalam penggunaan katakata yang mempunyai sinonim; (3) kejelasan tulisan yang dibuat; dan (4) pengembangan paragraf yang baik dan benar.

3. Tahap Revisi

Adapun, kegiatan penyuntingan dan perbaikan dapat dilakukan dengan langkah-langkah (1) membaca keseluruhan tulisan atau karangan; (2) menandai hal-hal yang perlu diperbaiki atau memberi catatan bila ada hal-hal yang harus diganti, ditambahkan, dan disempurnakan; serta
(3) melakukan perbaikan sesuai dengan temuan saat penyuntingan.

\subsection{Definisi Paragraf}

Secara umum paragraf adalah gabungan dari beberapa kalimat. Oshima dan Hogue (2006) mengatakan, "Paragraf adalah kumpulan beberapa kalimat yang membahas satu ide pokok." (hlm. 2). Sedikit berbeda dengan Hikmat dan Solihati (2013) mengatakan, "Paragraf biasanya terdiri dari pikiran, gagasan, atau ide pokok yang dijelaskan dengan kalimat pendukung." (hlm. 60). Dari dua pendapat itu disimpulkan bahwa paragraf merupakan gabungan atau rangkaian beberapa kalimat dengan satu topik atau satu gagasan dan didukung oleh kalimatkalimat penjelas.

\subsection{Syarat Paragraf}

Syarat paragraf yang benar adalah harus kohesi dan koherensi. Berikut ini adalah penjelasan kedua syarat paragraf yang benar tersebut menurut (Suparno dan Yunus, 2009, hlm. 3.19-3.20).

\subsubsection{Kesatuan/Kohesi}

Kesatuan atau kekohesian paragraf adalah suatu paragraf harus memiliki satu pikiran yang jelas. Paragraf yang benar hanya memiliki satu kalimat topik di dalamnya. Oleh sebab itu, kalimat topik atau ide pokok tersebut harus diperjelas dengan kalimat-kalimat penjelas dengan topik yang sama sehingga informasi dalam paragraf itu jelas.

\subsubsection{Kepaduan/Koherensi}

Kepaduan atau kekoherensian paragraf adalah paragraf yang dibentuk oleh hubungan-hubungan antar kalimat. Dengan kata lain bahwa kalimat yang satu dengan kalimat yang lain memiliki hubungan. Artinya, paragraf itu harus dibangun oleh kalimat-kalimat yang saling mendukung satu sama lain dan tetap satu topik.

Agar lebih mudah melihat suatu paragraf apakah sudah koherensi atau belum, terlebih dahulu kita harus unsur- 
unsur pembentuk kepaduan itu sendiri. Berikut ini unsur pembentuk kepaduan suatu paragraf menurut Setiawan (2014:3.7-3.15 ) adalah: (1) adanya referensi, (2) adanya konjungsi, (3) adanya substitusi, (4) adanya ellipsis, dan (5) adanya pengulangan.

Perhatikan contoh paragraf berikut ini!

Ada anggapan yang salah bahwa bahasa Indonesia tidak perlu dipelajari. Alasannya, orang Indonesia sudah tentu dapat berkomunikasi dalam bahasa Indonesia. Apalagi bila bahasa Indonesia hanya digunakan untuk berkomunikasi sehari-hari di lingkungan masyarakat. Cukuplah dengan kemampuan bahasa yang sekadarnya, asal maksudnya dapat diterima oleh lawan bicara. Itulah sebabnya, pelajaran Bahasa Indonesia di sekolah hanya dianggap sebagai salah satu materi pelajaran tanpa memerhatikan hasil akhirnya, yaitu kemampuan berbahasa (Rahayu, 2007, hlm. 98).

Paragraf di atas dapat dijabarkan sebagai berikut.

Kalimat Topik: Ada anggapan yang salah bahwa orang Indonesia tidak perlu belajar bahasa Indonesia.

Beberapa pikiran penjelas:

a. Bahasa Indonesia telah digunakan dalam masyarakat.

b. Komunikasi sudah lancar dengan bahasa yang sekadarnya.

c. Pelajaran Bahasa Indonesia tidak mendapatkan perhatian.

Kalimat-kalimat penjelas di atas mempunyai hubungan satu sama lain dan memberikan penjelasan terhadap adanya anggapan yang salah tentang bahasa Indonesia.

\subsection{Struktur Paragraf}

Suatu paragraf yang baik hanya memunyai satu kalimat topik dan minimal satu kalimat penjelas. Namun, akan lebih baik jika kalimat topik dalam suatu paragraf dijelaskan dengan beberapa kalimat penjelas sehingga menjadi lebih jelas. Selain itu, ada beberapa paragraf yang juga dilengkapi dengan kalimat kesimpulan. Berikut ini adalah penjabaran ketiga struktur paragraf menurut (Oshima dan Hogue, 2006, 3-5).

\subsubsection{Kalimat Topik}

Kalimat topik sama dengan kalimat pokok atau pikiran utama. Kalimat topik harus memiliki sebuah topik dan ide pengontrol. Ide pengontrol adalah batasanbatasan untuk mengembangkan paragraf. Jadi, kalimat-kalimat penjelas untuk menjelaskan kalimat topik tidak boleh keluar atau berbeda dari ide pengontrol. Berikut ini merupakan hal-hal yang perlu diperhatikan dalam kalimat topik.

a) Kalimat topik adalah kalimat yang lengkap dan dapat berdiri sendiri.

b) Kalimat topik terdiri dari dua bagian, yaitu topik dan ide pengontrol.

c) Kalimat topik merupakan pernyataan umum yang mengindikasikan kalimat utama dalam paragraf.

d) Kalimat topik tidak memberikan pernyataan yang spesifik atau masih bersifat umum.

Perhatikan beberapa contoh kalimat topik berikut!

a) Ada dua jenis uang di Indonesia, yaitu uang kertas dan uang logam.

b) Lima langkah menjadi mahasiswa Universitas Tridinanti Palembang.

Keterangan :

Tulisan dicetak miring disebut sebagai topik

Tulisan dicetak tebal disebut sebagai ide pengontrol

Kalimat topik biasanya terletak pada awal paragraf. Namun, beberapa penulis yang sudah mahir biasanya meletakkan kalimat topik di tempat yang lain, tetapi letak terbaik sebuah kalimat topik, yaitu di awal paragraf.

\subsubsection{Kalimat Penjelas}

Kalimat penjelas pada paragraf berfungsi untuk memperjelas kalimat topik. Kalimat penjelas dapat dibuat dengan cara menjabarkan ide-ide 
pengontrol pada kalimat topik. Kalimat ini bertujuan memberikan kejelasan informasi kalimat topik dalam paragraf. Meskipun demikian, kejelasan informasi ini harus tidak menyimpang dari topik pada kalimat topik dalam paragraf. Hal ini dapat dijabarkan berupa perincian-perincian, contoh-contoh dan lain-lain.

\subsubsection{Kalimat Kesimpulan}

Kebanyakan suatu paragraf biasanya hanya terdiri atas kalimat topik dan kalimat penjelas. Padahal, selain itu paragraf dapat ditambahkan dengan kesimpulan. Kalimat kesimpulan bertujuan untuk memberikan penanda akhir dari suatu paragraf. Kalimat ini juga memberikan poin-poin penting dari kalimat sebelumnya. Hal ini dilakukan dengan cara meringkas poin-poin utama pada paragraf dan dengan mengulang kalimat topik dengan kalimat yang berbeda. Namun, perlu diperhatikan penggunaan kata hubung spesifik (jadi, oleh sebab itu, oleh karena itu, kesimpulannya, dll) karena dapat mengubah jenis paragraf.

\subsection{Interaksi Pembelajaran}

Dalam kegiatan pembelajaran pasti akan menghasilkan suatu interaksi. Menurut Ibrahim dan Syaodih (2010) dalam proses kegiatan belajar mengajar pasti terdapat interaksi. Interaksi dalam kegiatan belajar mengajar akan terjadi proses pengaruh dan memengaruhi. Interaksi tersebut biasanya melibatkan antara siswa-dengan siswa, guru dengan siswa dan dosen-mahasiswa atau bahkan sebaliknya dengan tujuan yang ingin dicapai. Interaksi-interaksi tersebut terjadi secara bergantian atau timbal balik (hlm.31-32).

\section{METODE PENELITIAN}

Penelitian ini mengunakan metode kombinasi antara kualitatif dan kuantitatif. Moelong (2014) berpendapat bahwa penelitian kualitatif adalah penelitian yang bermaksud untuk memahami fenomena tentang apa yang dialami oleh subjek penelitian misalnya perilaku, persepsi, motivasi, tindakan, dll (hlm. 6).

Secara keseluruhan penelitian ini berusaha mendeskripsikan kata-kata dan bahasa pada suatu konteks. Sementara itu, menurut Sukmadinata (2010) bahwa penelitian kuantitatif adalah penelitian yang membahas fenomena-fenomena secara objektif. Objektivitas data dilihat dari pengolahan angka-angka dengan statistik dan uji coba terkontrol (hlm. 53).

Penelitian ini menggunakan metode kombinasi antara kualitatif dan kuantitatif karena peneliti menggunakan tiga instrumen, angket, observasi, tes. Angket dan observasi sebagai teknik pengumpulan data pada metode penelitian kualitatif. Angket yang digunakan adalah angket semi terbuka sedangkan observasi yang digunakan adalah observasi berperan serta. Berikutnya adalah instrumen tes. Tes ini peneliti gunakan sebagai teknik pengumpulan data pada metode penelitian kuantitatif. Berdasarkan tiga instrumen inilah peneliti menjawab dan menyimpulkan hasil penelitian.

\subsection{Lokasi dan Subjek Penelitian}

Penelitian ini dilaksanakan di FKIP Program Studi Pendidikan Bahasa dan Sastra Indonesia dan Pendidikan Bahasa Inggris Universitas Tridinanti Palembang. Subjek penelitian ini adalah mahasiswa semester II. Subjek penelitian ini dipilih atas dasar pertimbangan bahwa mahasiswa semester II sudah diajarkan Mata Kuliah Menulis. Salah satu materinya adalah menulis paragraf. Subjek penelitian ini sebanyak 35 mahasiswa yang terbagi atas 17 mahasiswa Prodi Pendidikan Bahasa dan Sastra Indonesia dan 18 Mahasiswa Prodi Pendidikan Bahasa Inggris. Penentuan mahasiswa yang akan dijadikan subjek penelitian ini menggunakan teknik purposive sampling. Sukardi (2016) berpendapat bahwa teknik purposive sampling adalah cara menentukan sampel dengan tujuan tertentu untuk memperoleh informasi yang relevan 
Interaksi Pembelajaran Menulis Paragraf Deduktif pada

Mahasiswa Fkip Universitas Tridinanti Palembang (Doni Samaya)

dengan penelitian yang dilakukan (hlm. $64)$.

\subsection{Teknik Pengumpulan Data}

Pengumpulan data dalam penelitian ini menggunakan tiga instrumen, yaitu angket, tes, dan observasi. Arikunto (2010) mengemukakan bahwa tes adalah serentetan pertanyaan atau latihan serta alat lain yang digunakan untuk mengukur keterampilan, pengetahuan intelegensi, kemampuan atau bakat yang dimiliki oleh individu atau kelompok (hlm.193). Teknik ini bertujuan untuk memperoleh informasi tentang kemampuan mahasiswa dalam menulis paragraf. Bentuk tes yang digunakan adalah unjuk kerja menulis.

Selanjutnya, teknik pengumpulan data yang digunakan adalah observasi berperanserta. Sugiyono (2016) berpendapat bahwa observasi berperan serta merupakan teknik yang melibatkan langsung peneliti untuk melakukan observasi secara langsung atau tak berstruktur terhadap subjek penelitiannya (hlm. 197). Maksudnya, dengan ini seorang peneliti dapat mengambil data sekaligus mengamati subjek penelitian secara langsung sehingga data yang diperoleh lebih lengkap.

Selain menggunakan tes dan observasi, angket juga digunakan peneliti dalam mengumpulkan data. Angket yang digunakan dalam penelitian ini adalah angket semi terbuka. Angket semi terbuka adalah angket yang memungkinkan adanya kesempatan bagi mahasiswa dalam memberikan jawaban lain walaupun pada soal sudah diberi opsi jawaban. Peneliti memberikan 15 butir pertanyaan seputar konsep umum paragraf.

\subsection{Uji Validitas dan Reliabilitas}

Dalam penelitian ini, juga dilakukan validitas dan reliabilitas instrumen yang digunakan. Hal ini dilakukan dengan tujuan agar instumen penelitian menjadi layak digunakan dan dapat dipercaya. Baik validitas maupun reliabilitas suatu isntrumen dapat dilakukan dengan berbagai cara yang disesuaikan dengan jenis instrumen penelitiannya. Berikut ini adalah penjelas validitas dan reliabilitas penelitian.

Validitas instrumen yang peneliti gunakan adalah validitas isi. Menurut Sugiyono (2016) validitas isi adalah validitas yang dapat dilakukan dengan membandingkan antara isi instrumen dengan materi yang sedang diteliti (hlm. 177). Dengan kata lain, validitas isi dapat dibantu menggunakan kisi-kisi instrumen. Kisi-kisi ini harus disesuaikan dengan indikator pembelajaran dan rubrik penilaian dari variabel yang hendak diteliti.

Reliabilitas instrumen yang peneliti gunakan adalah reliabilitas internal. Sugiyono (2016) mengatakan bahwa reliabilitas internal adalah reliabilitas yang dilakukan dengan menguji dan menganalisis instrumen dengan teknik tertentu (hlm. 178). Dalam hal ini, peneliti menggunakan reliabilitas instrumen unjuk kerja yang didasarkan dari konsistensi nilai dari dua rater/ penelaah. Setelah penilaian dari dua rater diperoleh, peneliti melakukan penghitungan data tersebut dengan rumus korelasi pearson product moment melalui program SPSS 23. Hal ini dilakukan untuk memperoleh derajat reliabilitas/ konsistensi instrumen dari nilai yang diberikan dua rater.

\subsection{Teknik Analisis Data}

Penganalisisan data dalam penelitian ini menggunakan teknik kombinasi antara kuantitatif dan kualitatif atau pendeskripsian. Lembar tes unjuk kerja mahasiswa dianalisis dengan merujuk rubrik penilaian penulisan paragraf. Hasil tes unjuk kerja ini dianalisis atau dinilai oleh dua penelaah/ rater. Setelah itu, hasil nilai dari dua rater dianalisis dengan program SPSS 23 menggunakan teknik korelasi pearson product moment dan dideskripsikan secara jelas. Hal ini dilakukan dengan tujuan untuk mengetahui reliabilitas/ konsistensi tes 
unjuk kerja menulis paragraf deduktif berdasarkan dua nilai yang diberikan oleh penelaah/rater.

Begitu juga dengan data observasi dan angket semi tertutup untuk mahasiswa akan dideskripsikan dan dipersentasekan. Setelah diperoleh kedua nilai tersebut barulah dapat disimpulkan interaksi pembelajaran menulis paragraf deduktif dan faktor-faktor yang memengaruhi mahasiswa dalam menulis paragraf deduktif.

\section{HASIL DAN PEMBAHASAN \\ 4.1 Analisis}

\subsubsection{Faktor yang Memengaruhi Mahasiswa dalam Menulis Paragraf Deduktif}

Berdasarkan hasil angket, peneliti menyimpulkan bahwa terdapat beberapa faktor yang memengaruhi subjek penelitian dalam menulis paragraf deduktif. Rinciannya adalah sebagai berikut.

Tabel 1 Rekapitulasi Hasil Angket

\begin{tabular}{|c|c|}
\hline No & $\begin{array}{l}\text { Faktor pemengaruh menulis } \\
\text { paragraf }\end{array}$ \\
\hline 1 & $\begin{array}{l}\text { Tidak semua subjek penelitian } \\
\text { paham dengan konsep bahwa } \\
\text { dalam satu paragraf hanya boleh } \\
\text { membahas satu topik. }\end{array}$ \\
\hline 2 & $\begin{array}{l}\text { Tidak semua subjek penelitian } \\
\text { paham dengan struktur }\end{array}$ \\
\hline 3 & $\begin{array}{l}\text { Tidak semua subjek penelitian } \\
\text { paham syarat paragaf. }\end{array}$ \\
\hline 4 & $\begin{array}{l}\text { Tidak semua subjek penelitian } \\
\text { memikirkan konsep, struktur, dan } \\
\text { syarat paragraf dalam menulis } \\
\text { paragraf deduktif. }\end{array}$ \\
\hline 5 & $\begin{array}{l}\text { Tidak semua subjek penelitian } \\
\text { mengetahui batasan paragraf } \\
\text { (kapan pindah dan tetap dalam } \\
\text { satu paragraf). }\end{array}$ \\
\hline 6 & $\begin{array}{l}\text { Tidak semua subjek penelitian } \\
\text { paham dengan definisi paragraf } \\
\text { deduktif. }\end{array}$ \\
\hline 7 & $\begin{array}{l}\text { Adanya kesulitan mahasiswa } \\
\text { dalam menulis paragraf, yaitu }\end{array}$ \\
\hline
\end{tabular}

kurangnya kosakata dan pengetahuan; kurangnya kosakata dan pemahaman konsep; kurangnya pemahaman tentang struktur dan syarat paraagraf serta kesulitan mengorganisasikan ide.

Berdasarkan hasil tes menulis paragraf deduktif subjek penelitian, peneliti menemukan beberapa kesalahan. Adapun bentuk kesalahan paragraf deduktif yang dibuat subjek penelitian adalah seabagai berikut.

Tabel 2 Rekapitulasi Hasil Tes

\begin{tabular}{clc}
\hline No & \multicolumn{3}{c}{ Kesalahan Dalam Paragraf } \\
\hline 1 & $\begin{array}{l}\text { Sebagian subjek penelitian } \\
\text { membuat paragraf yang banyak } \\
\text { topik. }\end{array}$ \\
\hline 2 & $\begin{array}{l}\text { Sebagian subjek penelitian } \\
\text { menuliskan paragraf dengan } \\
\text { kalimat yang rancu. }\end{array}$ \\
\hline 3 & $\begin{array}{l}\text { Sebagian subjek penelitian } \\
\text { menuliskan paragraf yang tidak } \\
\text { kohesi dan tidak koherensi. }\end{array}$ \\
\hline 4 & $\begin{array}{l}\text { Sebagian subjek penelitian } \\
\text { menuliskan paragraf dengan }\end{array}$ \\
& struktur tidak jelas. \\
\hline 5 & $\begin{array}{l}\text { Sebagian subjek penelitian } \\
\text { menuliskan paragraf dengan } \\
\text { konsep yang salah. }\end{array}$ \\
\hline 6 & $\begin{array}{l}\text { Sebagian subjek penelitian } \\
\text { melakukan penyingkatan pada } \\
\text { paragraf. }\end{array}$ \\
\hline 7 & $\begin{array}{l}\text { Sebagian subjek penelitian salah } \\
\text { menerapkan kata hubung biasa } \\
\text { dan kata hubung berpasangan. }\end{array}$ \\
\hline 8 & $\begin{array}{l}\text { Sebagian subjek penelitian masih } \\
\text { salah menerapkan huruf kapital, } \\
\text { kata depan dan awalan. }\end{array}$ \\
adalah \\
rater. Dua nilai ini hanya secara umum. \\
tabel rekapitulasi nilai dari dua
\end{tabular}


Tabel 3 Rekapitulasi Nilai Tes

No $\begin{gathered}\text { Nama } \\ \begin{array}{c}\text { Maha- } \\ \text { siswa }\end{array}\end{gathered} \quad \begin{gathered}\text { Nilai } \\ \text { Rater 1 }\end{gathered} \quad \begin{gathered}\text { Nilai } \\ \text { Rater } 2\end{gathered}$

\begin{tabular}{|c|c|c|c|}
\hline 1 & JK & 62 & 64 \\
\hline 2 & DA & 60 & 64 \\
\hline 3 & IPD & 70 & 72 \\
\hline 4 & RBS & 60 & 62 \\
\hline 5 & SZB & 60 & 64 \\
\hline 6 & FYP & 62 & 66 \\
\hline 7 & NP & 60 & 62 \\
\hline 8 & FGS & 60 & 60 \\
\hline 9 & FSA & 62 & 64 \\
\hline 10 & $\mathrm{AP}$ & 60 & 62 \\
\hline 11 & AJ & 65 & 65 \\
\hline 12 & SORS & 65 & 67 \\
\hline 13 & ASS & 65 & 68 \\
\hline 14 & VOS & 60 & 62 \\
\hline 15 & LS & 60 & 63 \\
\hline 16 & TA & 60 & 62 \\
\hline 17 & NES & 62 & 64 \\
\hline 18 & $\mathrm{AU}$ & 62 & 65 \\
\hline 19 & SW & 70 & 71 \\
\hline 20 & AS & 60 & 64 \\
\hline 21 & $\overline{Y P}$ & 62 & 64 \\
\hline 22 & AN & 60 & 64 \\
\hline 23 & $\overline{\mathrm{DA}}$ & 65 & 66 \\
\hline 24 & $\mathrm{RL}$ & 65 & 67 \\
\hline 25 & RU & 66 & 68 \\
\hline 26 & SF & 60 & 64 \\
\hline 27 & NG & 65 & 66 \\
\hline 28 & TRK & 66 & 66 \\
\hline 29 & MT & 60 & 62 \\
\hline 30 & MFK & 65 & 66 \\
\hline 31 & YA & 66 & 68 \\
\hline 32 & NS & 60 & 62 \\
\hline 33 & WWR & 65 & 66 \\
\hline 34 & MRP & 66 & 70 \\
\hline 35 & ITNH & 60 & 64 \\
\hline
\end{tabular}

Berdasarkan nilai dari dua rater atau penelaah tentang tes menulis paragraf deduktif. Peneliti melakukan uji reliabilitas tes. Akan tetapi, hal ini hanya digunakan untuk melihat pengetahuan subjek penelitian dalam menulis paragraf deduktif.

\section{Tabel 4 Deskripsi Pearson Product Moment Paragraf Deduktif}

\begin{tabular}{llrr}
\hline \multicolumn{3}{c}{ Correlations } \\
\hline Rater 1 & $\begin{array}{l}\text { Pearson } \\
\text { Correlation }\end{array}$ & 1 &, $914^{* *}$ \\
\cline { 2 - 4 } & Sig. (2-tailed) & &, 000 \\
\cline { 2 - 4 } & $\mathrm{N}$ & 35 & 35 \\
\hline Rater 2 & Pearson &, $914^{* *}$ & 1 \\
& Correlation &, 000 & Rater 2 \\
\cline { 2 - 4 } & Sig. (2-tailed) & 35 & 35 \\
\cline { 2 - 3 } & $\mathrm{N}$ & & \\
\hline \multirow{2}{**}{$\begin{array}{l}\text { ** Correlation is significant at the 0.01 level (2- } \\
\text { tailed). }\end{array}$} &
\end{tabular}

Berdasarkan penghitungan nilai dari dua rater menggunakan pearson product moment pada SPSS 23, diperoleh bahwa nilai signifikansi 0,000. Artinya, terdapat hubungan masing-masing nilai dari rater dan lebih kecil dari 0,05. Selanjutnya, derajat konsistensi nilai dari dua rater adalah 0,914. Jadi, disimpulkan bahwa reliabilitas nilai dari dua rater menunjukkan derajat koefisien korelasi yang sangat tinggi.

\subsubsection{Interaksi Pembelajaran dalam Menulis Paragraf Deduktif pada Mahasiswa FKIP Universitas Tridinanti Palembang}

Untuk mengetahui hal ini penelitian menggunakan observasi. Observasi yang digunakan adalah observasi berperan serta. Obeservasi ini bertujuan untuk mengetahui bagaimana pemahaman konsep dan praktik mahasiswa dalam menulis paragraf. Sebelumnya, konsep dan praktik menulis paragraf deduktif ini sudah dipelajari pada mata kuliah di semester yang lalu atau bahkan ketika masih di sekolah menengah atas. Karena peneliti menggunakan observasi berperan serta, subjek penelitian tidak menyadari bahwa yang mereka kerjakan itu bukan sekadar tugas melainkan sebagai tes sekaligus 
pengamatan oleh peneliti. Hal ini membuat subjek penelitian bersikap lebih natural.

Berdasarkan observasi kepada mahasiswa ketika pengambilan data, peneliti menyimpulkan bahwa ada tiga hal yang terjadi dalam pembelajaran menulis paragraf deduktif. Tiga hal tersebut adalah interaksi antarmahasiswa, interaksi mahasiswa dengan dosen, dan interaksi dosen dengan mahasiswa. Adapun penjabaran ketiga hal di atas adalah sebagai berikut.

\section{a. Interaksi Antarmahasiswa}

Terdapat beberapa interaksi antarmahasiswa dalam menulis paragraf deduktif. Penjabaraanya adalah sebagai berikut.

Pertama, mereka memikirkan terlebih dahulu konsep paragraf deduktif yang akan ditulis. Dalam merealisasikan hal ini, mereka ada yang langsung mengingat kembali konsep paragraf deduktif yang telah dipelajari sebelumnya. Selain itu, ada juga subjek penelitian yang lupa dengan konsep paragraf deduktif yang telah dipelajari sebulumnya sehingga mereka mencari di internet.

Kedua, mereka memikirkan topik yang peneliti berikan. Dalam hal ini topik yang peneliti berikan adalah tentang jurusan atau prodi mereka masing-masing. Ketika menentukan topik tersebut, ada sebagian subjek penelitian yang langsung paham. Artinya meraka langsung mendapatkan ide untuk dituangkan dalam paragraf. Akan tetapi, ada juga yang kebingungan harus memulai dari mana terlebih dahulu. Bahkan ada yang sampai bertanya kepada temannya yang sudah paham.

Ketiga, setelah memikirkan kedua langkah tersebut, mereka langsung menuliskan ide yang dipikirkan dalam bentuk kalimat sehingga terbentuklah paragraf deduktif. Sesekali, mereka saling baca hasil tulisan masing-masing. Lalu, mereka berdiskusi satu sama lain untuk mengetahui apakah paragraf hasil tulisannya sudah benar atau masih salah.
Misalnya: penggunaan huruf kapital, tanda baca, kejelasan makna kalimat, dll. Berdasarkan diskusi tersebut, ada subjek penelitian yang memperbaiki paragraf dan ada yang tetap pada pendapatnya masingmasing.

\section{b. Interaksi Mahasiswa dengan Dosen}

Terdapat beberapa interaksi antara mahasiswa dan dosen dalam menulis paragraf deduktif. Dalam hal ini dosen yang memberikan tugas menulis paragraf deduktif juga berperan sebagai peneliti. Adapun, perinciannya adalah sebagai berikut.

Pertama, mahasiswa bertanya bagaimana cara menulis paragraf deduktif. Walaupun sudah mengingat, mencari, dan mendiskusikan paragraf deduktif, subjek penelitian tampaknya masih belum jelas dengan konsep yang mereka baca dan pahami. Hal ini membuat mereka bertanya kepada peneliti tentang bagaimana cara menulis paragraf deduktif? Lalu, peneliti menjawab bahwa subjek penelitian harus memahami konsep paragraf deduktif. Setelah itu pikirkan topik yang telah ditentukan dan tuangkan hal itu ke dalam tulisan.

Kedua, mahasiswa menyampaikan bahwa ide-ide tentang konsep yang dipikirkan sudah ada bahkan banyak, tetapi mereka kebingungan harus memulai dari mana. Peneliti menjawab bahwa subjek penelitian harus banyak membaca, karena mampu tidaknya kita menulis secara tidak langsung dipengaruhi oleh banyaknya tulisan yang dibaca. Semakin banyak tulisan yang dibaca maka akan semakin banyak kosakata dan pemahaman yang diperoleh untuk diterapkan pada tulisan yang akan dibuat.

Ketiga, memberikan petunjuk teknis penulisan paragraf deduktif. Untuk merespons belum pahamnya subjek penelitian dalam menulis paragraf deduktif, maka peneliti menyampaikan beberapa kata kunci dalam menulis paragraf ini. Kata kunci tersebut di antaranya adalah definisi dan pola 
paragraf deduktif. Paragraf deduktif adalah paragraf yang kalimat utamanya terletak di awal paragraf. Pargraf ini berpola umum ke khusus. Artinya, kita harus menuliskan topik umumnya terlebih dahulu pada kalimat utama dan dari kalimat utama itu dijabarkanlah beberapa kalimat penjelas. Walaupun demikian, subjek penelitian masih kesulitan dan belum paham.

Keempat, subjek penelitian mengerjakan dan mengumpulkan paragraf hasil tulisannya. Setelah ketiga interaksi di atas dilaksanakan, subjek penelitian barulah mulai menulis paragraf deduktif. Namun, itu hanya berlaku untuk yang sudah paham dengan konsep yang peneliti sampaikan sebelumnya, sedangkan yang belum paham membutuhkan sedikit waktu untuk berpikir kembali agar dapat menulis paragraf deduktif. Selanjutnya, dalam waktu beberapa menit kemudian atau kurang lebih 40 menit dari ketiga interaksi itu, mereka pun mengumpulkan hasil tulisannya.

\section{c. Interaksi Dosen dengan Mahasiswa}

Ada enam bentuk interaksi pembelajaran dalam menulis paragraf deduktif antara dosen (peneliti) dengan subjek penelitian. Rinciannya adalah sebagai berikut.

Pertama, peneliti mengoreksi paragraf deduktif hasil tulisan subjek penelitian. Setelah dikoreksi, peneliti menemukan beberapa kesalahan subjek penelitian, di antaranya topik dalam paragraf lebih dari satu dan tidak adanya keterkaitan antarkalimat dalam paragraf. Hal ini terjadi karena subjek penelitian belum paham atau bahkan lupa dengan konsep yang telah dipelajari sebelumnya. Konsep ini sebenarnya sudah ada pada struktur paragraf dan syarat paragraf. Akan tetapi belum diterapkan secara maksimal oleh subjek penelitian.

Kedua, untuk menindaklanjuti masalah pada interaksi pertama, peneliti berupaya untuk mengarahkan ke penulisan paragraf yang benar. Salah satunya dengan menyampaikan struktur paragraf deduktif. Struktur paragraf deduktif itu ada tiga, yaitu kalimat utama, kalimat penjelas, dan kalimat kesimpulan. Kalimat utama adalah kalimat yang berpola umum. Kalimat ini memperkenalkan topik dan berisi topik dan ide pengontrol. Kalimat penjelas adalah kalimat yang dikembangkan dari kalimat utama. Namun, yang perlu diperhatikan, bahwa kalimat penjelas harus berpatokan dengan ide pengontrol pada kalimat utama. Kalimat penjelas tidak boleh membahas atau keluar selain dari ide pengontrol. Kalimat kesimpulan adalah kalimat yang berupa ringkasan mengenai isi paragraf yang dituangkan pada kalimatkalimat sebelumnya. Kalimat ini juga dapat diterapkan dengan mengulang kembali kalimat utama dengan kalimat yang berbeda, tetapi tidak boleh menggunakan kata hubung yang spesifik.

Ketiga, masih berkaitan dengan interaksi yang pertama, peneliti menyampaikan juga syarat paragraf. Syarat paragraf itu ada tiga, yaitu kesatuan (kohesi), kepaduan (koherensi), dan kelengkapan. Kesatuan adalah suatu paragraf harus memiliki satu ide yang jelas. Artinya suatu paragraf hanya boleh membahas satu topik tidak lebih. Kepaduan adalah suatu paragraf itu harus disusun oleh kalimat yang padu. Artinya, antarkalimat pembentuk suatu paragraf harus saling berkaitan satu sama lain. Kelengkapan adalah suatu paragraf itu harus menyajikan informasi yang jelas. Artinya, suatu paragraf yang baik dan benar itu minimal terdiri dari $4-5$ kalimat supaya informasi yang hendak disampaikan menjadi jelas.

Keempat, peneliti menyampaikan buat kerangka paragraf. Agar lebih mudah dan terarah dalam menulis paragraf, tidak ada salahnya sebelum menulis buat kerangka paragraf terlebih dahulu. Hal ini penting mengingat bahwa kerangka sama dengan rencana atau gambaran umum tulisan yang akan dibuat sehingga lebih terarah. Setelah kerangka paragraf dibuat barulah kita 
kembangkan menjadi sebuah paragraf. Hal ini tentu mempermudah alur pemikiran kita sehingga paragraf menjadi kohesi dan koherensi.

Kelima, peneliti menyampaikan kapan pindah atau tetap dalam satu paragraf. Pada dasarnya kalimat-kalimat itu tetap boleh dalam satu paragraf kalau masih dalam satu topik sesuai dengan syarat paragraf, yaitu kesatuan. Jadi, jika kalimat-kalimat masih dalam satu topik, maka tulisan dituliskan tetap dalam satu paragraf. Begitu juga sebaliknya, jika kalimat-kalimat sudah beda topik maka tulisan dituliskan pada paragraf yang berbeda. Artinya, banyaknya kalimat tidak mempengaruhi pindah atau tetap dalam satu paragraf.

Keenam, peneliti menginstruksikan mahasiswa untuk memperbaiki paragraf. Setelah kelima interaksi di atas, peneliti meminta subjek penelitian untuk memperbaiki paragraf deduktif yang telah dibuat sebelumnya. Peneliti meminta subjek penelitian untuk menerapkan beberapa konsep yang telah dibahas bersama sehingga hasilnya tulisannya menjadi lebih baik.

\subsection{Pembahasan}

Penelitian ini dilakukan dengan tiga langkah. Langkah pertama adalah pemberian angket. Angket yang diberikan adakah angket semi terbuka. Artinya, angket ini memberikan kesempatan subjek penelitian memberikan jawabannya sendiri apabila kurang setuju dengan tiga opsi jawaban yang peneliti sediakan. Angket ini digunakan peneliti untuk menentukan faktor-faktor yang mempengaruhi subjek penelitian dalam menulis paragraf deduktif.

Adapun hasil angketnya secara umum adalah: mahasiswa pernah belajar paragraf; mahasiswa mengetahui definisi paragraf; mahasiswa mengetahui konsep paragraf; sebagian mahasiswa mengetahui struktur paragraf yang benar; sebagian mahasiswa mengetahui syarat paragraf yang benar; mahasiswa pernah menulis paragraf deduktif; sebagian mahasiswa memikirkan konsep, struktur, dan syarat dalam menulis paragraf deduktif; sebagian mahasiswa mengetahui batasan paragraf (pindah atau tetap) dalam menulis suatu paragraf; sebagian mahasiswa mengetahui kapan saatnya harus pindah dari satu paragraf; sebagian mahasiswa mengetahui kapan saatnya harus tetap dalam satu paragraf; sebagian mahasiswa mengetahui konsep paragraf deduktif; sebagian mahasiswa mengetahui hal pertama yang harus dilakukan ketika menulis paragraf deduktif; langkah-langkah mahasiswa dalam menulis paragraf deduktif; kesulitan mahasiswa dalam menulis paragraf deduktif; saran mahaisiswa terhadap pembelajaran paragraf deduktif.

Dari angket, peneliti menyimpulkan beberapa faktor yang mempengaruhi subjek penelitian dalam menulis paragraf deduktif.

1. Tidak semua subjek penelitian paham dengan konsep bahwa dalam satu paragraf hanya boleh membahas satu topik.

2. Tidak semua subjek penelitian paham dengan struktur.

3. Tidak semua subjek penelitian paham syarat paragaf.

4. Tidak semua subjek penelitian memikirkan konsep, struktur, dan syarat paragraf dalam menulis paragraf deduktif.

5. Tidak semua subjek penelitian mengetahui batasan paragraf (kapan pindah dan tetap dalam satu paragraf).

6. Tidak semua subjek penelitian paham dengan definisi paragraf deduktif.

7. Adanya kesulitan mahasiswa dalam menulis paragraf, yaitu kurangnya kosakata dan pengetahuan; kurangnya kosakata dan pemahaman konsep; kurangnya pemahaman tentang struktur dan syarat paraagraf serta kesulitan mengorganisasikan ide.

8. Adanya saran subjek penelitian, yaitu sebaiknya penjelasan konsep dan latihan ditambah; metode dalam pembelajaran dipermudah/disesuaikan; proses latihan dan penugasan 
diperbanyak; kosakata dan pengetahuan ditingkatkan. Semua saran tersebut mengarah pada kesulitan subjek penelitian dalam menulis paragraf.

Langkah yang kedua, adalah pemberian tes kepada subjek penelitian. Tes ini berupa unjuk kerja menulis paragraf deduktif. Tes ini diberikan kepada subjek penelitian secara serta merta atau tanpa persiapan karena materi ini telah dipelajari sebelumnya.

Adapun pembahasan umum dari hasil tes unjuk kerja menulis paragraf deduktif: sebagian subjek penelitian membuat paragraf yang banyak topik; sebagian subjek penelitian menuliskan paragraf dengan kalimat yang rancu; sebagian subjek penelitian menuliskan paragraf yang tidak kohesi dan tidak koherensi.; sebagian subjek penelitian menuliskan paragraf dengan struktur tidak jelas; sebagian subjek penelitian menuliskan paragraf dengan konsep yang salah; sebagian subjek penelitian melakukan penyingkatan pada paragraf; sebagian subjek penelitian salah menerapkan kata hubung biasa dan kata hubung berpasangan; sebagian subjek penelitian masih salah menerapkan huruf kapital, kata depan dan awalan.

Langkah yang ketiga adalah observasi. Observasi yang digunakan adalah observasi berperan serta. Artinya, dalam pengambilan data, peneliti dapat secara langsung menyaksikan subjek penelitian. Dengan kata lain dalam penga,bilan data, peneliti sekaligus berperan sebagai dosen pengampu sehingga subjek penelitian menganggap bahwa tes yang diberikan peneliti hanya berupa tugas biasa diakhir pembelajaran. Dengan observasi ini data yang diperoleh menjadi lebih alami dan nyata karena subjek penelitian tidak menyadari kalau mereka sedang diamati dalam menulis paragraf deduktif. Hasil observasi ini, peneliti gunakan untuk menjawab rumusan masalah yang kedua, yaitu tentang interaksi pembelajaran menulis paragraf deduktif. Adapun hasil observasi peneliti terhadap subjek penelitian dalam menulis paragraf deduktif adalah sebagai berikut.

1. Adanya interaksi antarmahasiswa.

2. Adanya interaksi mahasiswa dengan dosen.

3. Adanya interaksi dosen dengan mahasiswa.

\section{PENUTUP}

\subsection{Simpulan}

Berdasarkan hasil penelitian dan pembahasan, disimpulkan sebagai berikut.

1. Berdasarkan analisis angket, peneliti menyimpulkan bahwa subjek penelitian masih kesulitan dalam membuat paragraf deduktif.

2. Berdasarkan tes unjuk kerja, peneliti menyimpulkan bahwa subjek penelitian membutuhkan pemahaman konsep paragraf deduktif (definisi, struktur, syarat dan batasannya) agar tidak salah dalam memberikan contoh.

3. Berdasarkan observasi, peneliti menyimpulkan adanya tiga interaksi dalam pembelajaran menulis paragraf deduktif.

\subsection{Saran}

Berdasarkan hasil penelitian, pembahasan, dan kesimpulan di atas, terdapat beberapa saran yang dapat diajukan.

1. Sebaiknya, para dosen bahasa Indonesia di FKIP Universitas Tridinanti Palembang menggunakan metode pengajaran yang tepat dan memperbanyak proses latihan menulis paragraf deduktif.

2. Dengan menggunakan penelitian ini sebagai data awal, penelitian ini dapat dilanjutkan dengan jenis penelitian lain. Misalnya: eksperimen, korelasi, PTK, dll. 


\section{DAFTAR PUSTAKA}

Arikunto, S. (2010). Prosedur penelitian suatu pendekatan praktik. Jakarta: Rineka Cipta.

Azis, A.W. (2015). "Koherensi paragraf dalam skripsi mahasiswa prodi pendidikan bahasa dan sastra indonesia".http://journal.fkipunilaki.ac.id/index.php/dia/article/d ownload/14/14 (Diunduh, 22 April 2019)

DePorter,B., \& Mike,H. (2008). Kuantum learning membiasakan belajar nyaman dan menyenangkan. Bandung: PT Mizan Pustaka.

Hikmat \& Solihati. (2013). Bahasa indonesia. Jakarta: PT Grasindo.

Ibrahim,R., \& Nana,S.N. (2010). Perencanaan pengajaran. Jakarta: Rineka Cipta.

Kurniawan,K. (2012). Bahasa indonesia keilmuan untuk perguruan tinggi. Bandung: PT Refika Aditama.

Mardiyah. (2016). “Keterampilan men-ulis bahasa indonesia melalui kemampuan mengembangkan struktur paragraf". http://www.

ejournal.radenintan.ac.id/index.php/t erampil/article/download/1340/1067 (Diunduh, 22 April 2019)

Moleong,L.J. (2014). Metodologi penelitian kualitatif edisi revisi. Bandung: PT Remaja Rosdakarya.

Nurgiayantoro,B. (2001). Menulis secara populer. Jakarta: Pustaka Jaya.

Oshima,A., \& Ann,H. (1999). Writing academic english. White Plains: Longman.

Pramesti \& Efendi. (2018). “Peningkatan hasil belajar menulis paragraf pada mku bahasa indonesia di universitas negeri padang melalui model stad (student team-achievement divisions) metode menulis berantai. https://jurnal. umk.ac.id/index.php/kredo/article/d ownload/2565/1468 (Diunduh, 22 April 2019)
Rahayu,M. (2007). Bahasa indonesia di perguruan tinggi: mata kuliah pengembangan kepribadian. Jakarta: Grasindo.

Setiawan,T. (2014). Wacana bahasa indonesia. Jakarta: Universitas Terbuka.

Sugiyono. (2016). Metode penelitian kombinasi. Bandung: Alfabeta.

Sukardi. (2016). Metodologi penelitian pendidikan kompetensi dan pendidikan. Jakarta: Bumi Aksara.

Sukmadinata,N. (2010). metodologi penelitian pendidikan. Bandung: PT Remaja Rosdakarya.

Suparno \& Yunus. (2009). Keterampilan dasar menulis. Jakarta: Universitas Terbuka.

Zainurrahman. (2013). menulis: dari teori hingga praktik (penawar racun plagiarisme). Bandung: Alfabeta 